\title{
Pre-Existing Diabetes Limits Survival Rate After Immune Checkpoint Inhibitor Treatment for Advanced Lung Cancer: A Retrospective Study in Japan [Corrigendum]
}

Hisanaga K, Uchino H, Kakisu N, et al. Diabetes Metab Syndr Obes. 2021;14:773-781.

Page 775, left column, third paragraph, line 4, the text “( $<<0.5)$ ” should read " $(\mathrm{p}<0.05)$ ".

Page 775, left column, second line from the bottom, the text " $11.3 \pm 20.8$ " should read " $113.0 \pm 20.8$ ".
Page 776, Table 1, Plasma glucose $(\mathrm{mg} / \mathrm{dl})$ row, Unmatched, Non-DM $(\mathrm{n}=64)$ column, the value " 11.3 \pm 20.8 " should read " $113.0 \pm 20.8$ ".

The authors apologize for these errors.

\section{Publish your work in this journal}

Diabetes, Metabolic Syndrome and Obesity: Targets and Therapy is an international, peer-reviewed open-access journal committed to the rapid publication of the latest laboratory and clinical findings in the fields of diabetes, metabolic syndrome and obesity research. Origina research, review, case reports, hypothesis formation, expert opinion and commentaries are all considered for publication. The manuscript management system is completely online and includes a very quick and fair peer-review system, which is all easy to use. Visit http://www.dovepress.com/testimonials.php to read real quotes from published authors. 